\title{
Vaccination strategies to protect goldfish Carassius auratus against Aeromonas hydrophila infection
}

\author{
V. Thanga Viji, K. Deepa, S. Velmurugan, M. Birdilla Selva Donio, J. Adlin Jenifer, \\ M. Michael Babu, T. Citarasu*
}

Centre for Marine Science and Technology, Manonmaniam Sundaranar University Rajakkamangalam, Kanyakumari District, Tamilnadu 629502, India

\begin{abstract}
Ornamental goldfish Carassius auratus were treated with whole cell (WC), extracellular product (ECP), outer membrane protein (OMP) and biofilm (BF) vaccines developed from the virulent Aeromonas hydrophila (AHV1; GenBank HQ331525.1) with and without the immunoadjuvant Asparagus racemosus. On various days post-vaccination (dpv), the treated fish were challenged with virulent $A$. hydrophila. These fish were monitored for survival, growth, specific bacterial reduction, and biochemical, haematological and immunological parameters. C. auratus attained $100 \%$ mortality within $7 \mathrm{~d}$ in non-vaccinated groups, whereas the vaccines helped to significantly ( $\mathrm{p} \leq 0.001)$ increase survival after 25 and $50 \mathrm{dpv}$. The vaccines with immunoadjuvant $\left(\mathrm{ECP}_{2}, \mathrm{OMP}_{2}\right.$ and $\mathrm{BF}_{2}$ treatments) helped to reduce the Aeromonas load after the challenge, and serum albumin, globulin and protein levels were significantly $(\mathrm{p}<0.01)$ improved in the $\mathrm{OMP}_{2}$ and $\mathrm{BF}_{2}$-treated groups. Haemoglobin and red blood cell counts were also significantly improved $(p<0.05)$ in the vaccinated groups compared to the control group. Additionally, haemagglutination occurred at the 1:12 dilution level in the vaccine plus immunoadjuvant-treated groups. Supplementing the vaccines with immunoadjuvant helped to improve phagocytosis to $54.07 \%$, serum bactericidal activity to $14.6 \%$ and the albumin:globulin ratio to $7.6 \%$ in $\mathrm{BF}_{2}$ after $50 \mathrm{dpv}$. Its positive effect significantly $(\mathrm{p}<0.05)$ increased in vaccinated groups compared to controls. Based on the results, especially with the OMP and BF vaccines, the immunoadjuvant $A$. racemosus helped to improve the efficiency of the vaccines. This approach will aid in the development of more efficient vaccines against bacterial infections affecting the aquaculture industry.
\end{abstract}

KEY WORDS: Ornamental fish · Biofilm • Outer membrane protein · OMP · Herbal immunoadjuvants

Resale or republication not permitted without written consent of the publisher

\section{INTRODUCTION}

Ornamental fishes are rapidly gaining importance because of their aesthetic value and their immense commercial value in export trade worldwide. Approximately $90 \%$ of freshwater ornamental fishes were reported to be captive-bred (Andrews 1990). Prominent among freshwater ornamental carps cultured in India are koi carp Cyprinus carpio and goldfish Carassius auratus. While aquaculture is in the phase of rapid development and growth, intensification of fish farming often leads to the emergence of infectious and parasitic diseases. Of the pathogencaused diseases, Aeromonas hydrophila and other closely related motile aeromonads hold the greatest importance for carp culturists (Daskalov 2006). Aeromonas sp. has been implicated in many exposed wound infections (Beaune et al. 1978). The ubiquitous, Gram-negative, and opportunistic bacterium $A$. hydrophila causes disease in several freshwater fish species such as cyprinoids (Rahman et al. 1997). A. hydrophila causes red fin disease, haemorrhagic septicaemia, motile aeromonad septicaemia and other infections in $C$. auratus. A. hydrophila infection in 
fishes has been reported to occur occasionally in Asian countries, including China, the Philippines, Thailand and India (Ebanks et al. 2004).

Antibiotics are frequently used in aquaculture to treat larval infections. However, this practice can also result in both microbial resistance and residual accumulation in tissue, leading to overall fish immunosuppression (Van Muiswinkel et al. 1985). Fish vaccination in the aquaculture industry has been considered to be very important in reducing economic losses caused by microbial diseases (Rahman \& Kawai 2000). The administration of vaccines against bacterial and viral diseases has demonstrated positive results in relation to scientific and economic approaches by reducing the chemical use (Costa 2004). Several different kinds of vaccines have been investigated and developed against Aeromonas hydrophila, including whole cell (WC), extracellular product (ECP), outer membrane protein (OMP), biofilm (BF) and lipopolysaccharide. Currently, however, no commercial vaccine exists. The interest in using immunostimulants, adjuvants and vaccine carriers in fish is heightened by issues of viral, bacterial, parasitic and fungal diseases that are limiting factors in culture at many fish farms, hatcheries and aquaculture stations. Newer vaccines include highly purified subunit antigens that are weakly immunogenic. Vaccine formulations often require adjuvants for increased immunological efficiency and better vaccination schedules (RuszalaMallon et al. 1988, Vogel 2000). Saponin-based adjuvants have the ability to modulate the cellmediated immune system, as well as to enhance antibody production, and have the advantage that only a low dose is needed for adjuvant activity (Oda et al. 2000). Saponins are steroid or triterpenoid glycosides (Riguera 1997) that induce a strong adjuvant effect to both T-dependent and T-independent antigens, which further induce strong cytotoxic CD8+ lymphocyte responses and potentiate the response to mucosal antigens (Kensil 1996). The present study focused on the comparative efficacy of various types of vaccines (WC, ECP, OMP and BF vaccines) with herbal adjuvants against $A$. hydrophila infection in the goldfish Carassius auratus.

\section{MATERIALS AND METHODS}

\section{Source of Aeromonas hydrophila vaccines}

A highly virulent strain of Aeromonas hydrophila (AHV1; GenBank: HQ331525.1) was used for the entire study. It was isolated from infected Carassius auratus (Thanga Viji et al. 2011).

Whole cell (WC). The WC vaccine was prepared by growing AHV1 overnight in tryptic soy broth (TSB) at $20^{\circ} \mathrm{C}$ for $20 \mathrm{~h}$ followed by inactivation using $0.6 \%$ formalin. The formalin was removed by spinning the culture at $1500 \times g(20 \mathrm{~min})$ at room temperature, washing with $0.85 \%$ saline and finally re-suspending in saline to $35 \mathrm{mg} \mathrm{ml}^{-1}$ (wet weight).

Extracellular products (ECP). ECP vaccine was prepared by following the method of Adams et al. (1988) with slight modification. AHV1 was cultured in $50 \mathrm{ml} \mathrm{TSB}$ at $20^{\circ} \mathrm{C}$ for $18 \mathrm{~h}$, with shaking at $110 \mathrm{rpm}$. The culture was subsequently centrifuged $(15000 \times$ $g, 10 \mathrm{~min}$ at $28^{\circ} \mathrm{C}$ ), and the supernatants were removed. The supernatants were again centrifuged $\left(25000 \times g, 30 \mathrm{~min}\right.$ at $\left.28^{\circ} \mathrm{C}\right)$ and filtered through $0.22 \mu \mathrm{m}$ filters. The filtrate contained the ECP. After estimating the protein from the filtrate, they were treated with $0.6 \%$ formalin for $1 \mathrm{~h}$. The formalin was washed away twice by adding $0.85 \%$ saline solution and centrifuging at $25000 \times g\left(30 \mathrm{~min}\right.$ at $\left.28^{\circ} \mathrm{C}\right)$. Finally, the ECP was re-suspended in saline solution and stored at $-20^{\circ} \mathrm{C}$ for future vaccine studies.

Outer membrane protein (OMP). At $t=24 \mathrm{~h}$, the AHV1 culture was harvested by centrifugation from TSB at $3000 \times g\left(20 \mathrm{~min}\right.$ at $\left.25^{\circ} \mathrm{C}\right)$. The cell pellets were washed twice in phosphate-buffered saline (PBS) and once in $10 \mathrm{mM}$ Tris-hydrochloride ( $\mathrm{pH}$ 7.5). Cells were re-suspended in Tris- $\mathrm{HCl}$ and sonicated at $50 \mathrm{~W}$ for $30 \mathrm{~s}$ (4 times on ice). Following sonication, the suspension was mixed with Sarkosyl for solubilization of the OMP and incubated at $25^{\circ} \mathrm{C}$ for $30 \mathrm{~min}$. After incubation, the suspension was centrifuged at $4000 \times g$ (20 $\mathrm{min})$, and the supernatant was collected. After centrifugation at $45000 \times g(45 \mathrm{~min})$, the pellet was collected and stored at $20^{\circ} \mathrm{C}$ until it was used.

Biofilm (BF). The BF vaccine was prepared according to Azad et al. (1997), with some modifications. Briefly, AHV1 was grown on acrylic sheets suspended in TSB, and the biofilm was harvested and heat-inactivated at $90^{\circ} \mathrm{C}$ for $30 \mathrm{~min}$. It was stored at $-20^{\circ} \mathrm{C}$.

\section{Quantitative and qualitative protein analysis of AHV1 vaccines}

The WC, ECP, OMP and BF supernatants obtained were re-suspended in PBS at pH 7.2, and protein was estimated according to the Bradford (1976) assay. Further, the above proteins were resolved in $10 \%$ SDS-PAGE (Laemmli 1970) to generate profiles. 


\section{Preparation of herbal immune adjuvant and experimental set-up}

Asparagus racemosus tuber powders were extracted with hot water at $100^{\circ} \mathrm{C}$ for at least $2 \mathrm{~h}$. The extracts were filtered, and the supernatants were condensed (using a rotary evaporator at $55^{\circ} \mathrm{C}$ ), lyophilized and stored at $4^{\circ} \mathrm{C}$. The extracts contained steroidal saponins possessing immunoadjuvant properties (Gautam et al. 2004).

Healthy goldfish Carassius auratus having a mean weight of $16.4 \pm 1$ (SD) g were purchased from J.J. Ornamental Fish Hatchery (Nagercoil, Tamil Nadu, India). They were transported to the laboratory and acclimatized in fiberglass-reinforced plastic aquaria (1000 l capacity) for $10 \mathrm{~d}$ to meet established laboratory conditions (10 h dark: $14 \mathrm{~h}$ light; temperature 28 $\pm 2^{\circ} \mathrm{C}$ ) and to assess their disease-free health status. They were fed with commercial feeds (Taiyo, China). After acclimatization, triplicate tanks containing 150 fish (50 fish $\operatorname{tank}^{-1}$ ) were maintained in each treatment group (Fig. 1). The tanks had a capacity of 5001 with a flow-through system having a water flow rate of $1 \mathrm{ml} \mathrm{min}{ }^{-1}$. The water quality parameters included quantified dissolved oxygen at 5.2 to $7.8 \mathrm{\mu g} \mathrm{l}^{-1}$ and $\mathrm{pH} 7.5$ to 8.1. The fish were fed ad libitum 2 to 3 times per day with formulated standard commercial pellet feed at a ratio of $10 \%$ of their body weight $\mathrm{d}^{-1}$

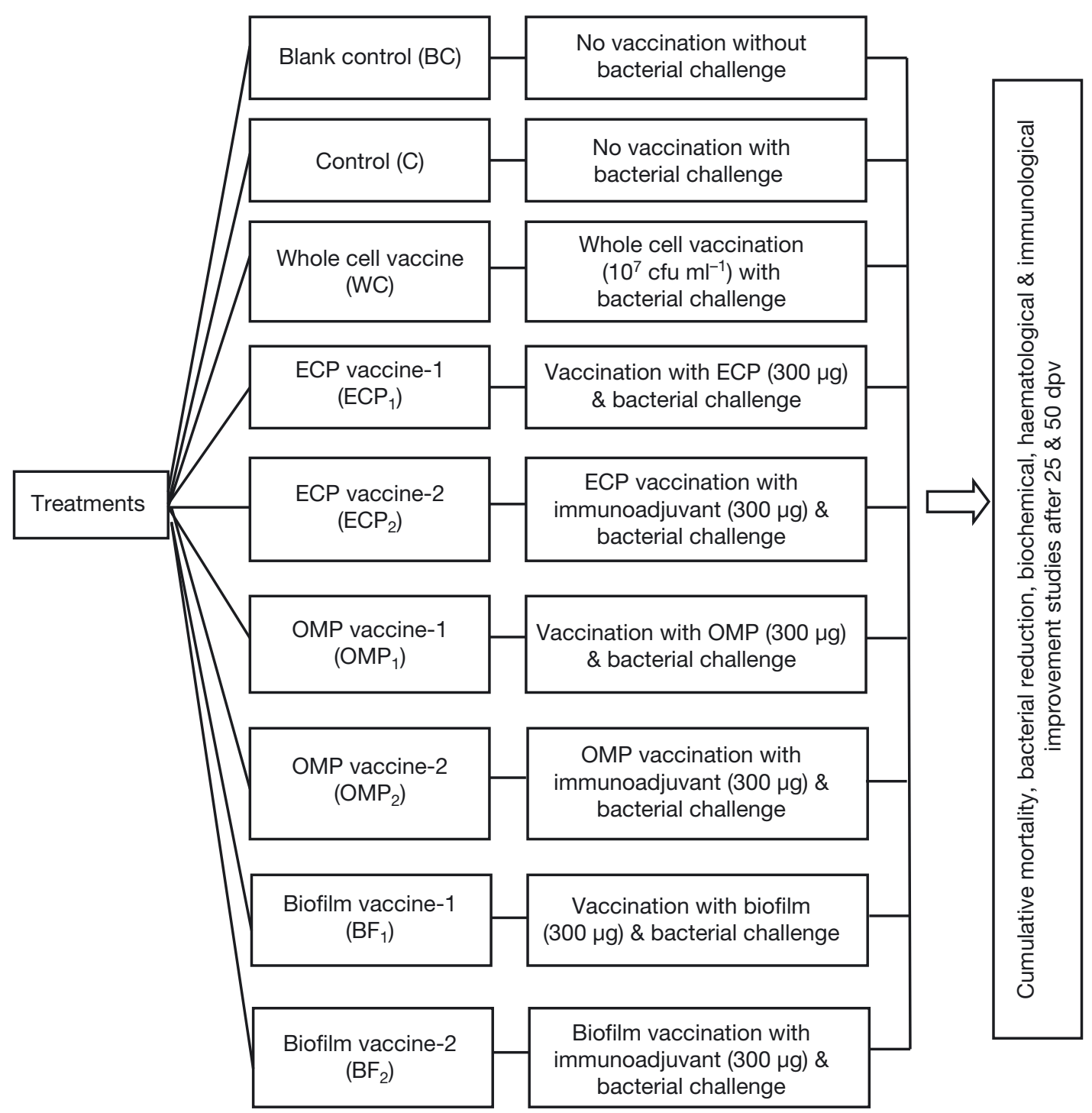

Fig. 1. Experimental set-up for vaccination strategies to protect goldfish Carassius auratus against Aeromonas hydrophila (strain AHV1) infection. dpv: days post vaccination 
throughout the period of study. A partial water change was performed daily to remove waste feed and faecal matter.

\section{Vaccine delivery and immunization}

Fish were vaccinated by intraperitoneal injections twice during the culture period. The first dose was delivered on Day 1, and the second dose was delivered on Day 25 of the experimental period. The dosage deliveries were WC vaccine at $10^{7} \mathrm{cfu} \mathrm{ml}^{-1}$ $\left(50 \mu \mathrm{lish}{ }^{-1}\right)$, and ECP, OMP and BF at $300 \mu \mathrm{g}$ of total protein per animal. The treatment groups $\left(\mathrm{ECP}_{2}\right.$, $\mathrm{OMP}_{2}$ and $\mathrm{BF}_{2}$ ) were also immunized with equal amounts of immunoadjuvant (Asparagus racemosus extracts), with antigens as adjuvant. The blank control groups had no antigen delivery and no bacterial challenge. The control group injected with PBS alone (without vaccine) was subject to bacterial challenge. The experimental and control fish were fed commercial feed 3 times $\mathrm{d}^{-1}$.

\section{Challenge with virulent Aeromonas hydrophila after 25 and 50 d post-vaccination (dpv)}

After 25 and $50 \mathrm{dpv}, 20$ fish from each group were intraperitoneally injected with $100 \mu$ l of live AHV1 at a $\mathrm{LC}_{50}$ dose concentration of $1 \times 10^{7} \mathrm{cfu} \mathrm{fish}^{-1}$. Survival was observed at $6 \mathrm{~h}$ intervals for a maximum of $10 \mathrm{~d}$, and the wet weight gain was calculated by deducting the initial weight from the final weight. The specific growth rate (SGR) was calculated by using the following formula:

$$
\operatorname{SGR}(\%)=\left(\ln W_{2}-\ln W_{1}\right) /\left(t_{2}-t_{1}\right) \times 100
$$

where $W_{2}=$ final weight at time $t_{2}$, and $W_{1}=$ initial weight at time $t_{1}$.

\section{Specific bacterial count in blood and muscle}

After the respective dpv period, blood was collected from the caudal vein of the challenged fish with a $1 \mathrm{ml}$ plastic syringe and rinsed with anticoagulant (10\% trisodium citrate), and $100 \mu$ l of blood was plated. The fish were then weighed aseptically and immersed in $50 \mathrm{ppm}$ formalin solution for $5 \mathrm{~min}$. They were washed thoroughly with sterilized water for $30 \mathrm{~s}$ to remove the remaining surface bacteria and disinfectant. The washed samples were homogenized with $5 \mathrm{ml}$ of $85 \%$ sterile saline and diluted up to 10 -fold. Using a sterilized pipette, a $100 \mu \mathrm{l}$ sample was taken and poured into Aeromonas isolation medium. Triplicates were maintained for each sample and incubated at $37^{\circ} \mathrm{C}$ for $48 \mathrm{~h}$.

\section{Biochemical, haematological and immunological parameters}

For the respective dpv period on Days 25 and 50, 25 randomly chosen fish from each experimental and control group were taken and anaesthetized with $50 \mathrm{mg}$ MS-222 dm $\mathrm{dm}^{-3}$ of water. Blood was collected from the caudal vein using a $1 \mathrm{ml}$ plastic syringe rinsed with anticoagulant. Part of the blood was transferred immediately and added to an equal volume of $10 \%$ trisodium citrate and then stored at $4{ }^{\circ} \mathrm{C}$. The remaining blood was kept at room temperature for $1 \mathrm{~h}$, without anticoagulant (to collect the serum), and stored at $-40^{\circ} \mathrm{C}$.

Saturated ammonium sulphate $\left(\mathrm{NH}_{4}\right)_{2} \mathrm{SO}_{4},(40 \%)$ was added to $100 \mu \mathrm{l}$ of serum in microcentrifuge tubes, mixed well and left to stand for $1 \mathrm{~h}$ at room temperature. The tubes were centrifuged at $10000 \times g(10 \mathrm{~min})$, and the supernatant (albumin fraction) from each tube was collected into separate tubes. The precipitate (globulin fraction) was then dissolved in $500 \mathrm{ml}$ of distilled water. The protein content of both albumin and globulin fractions was determined by the method of Lowry et al. (1951).

Haemoglobin levels were determined by the cyanomethaemoglobin method described by Van Kampen \& Zijlstra (1961). Total erythrocyte counts were performed using a haemocytometer (Hendricks 1952). The haemagglutination assay of serum samples was carried out by using a standardized method outlined by Sritunyalucksana et al. (1999) against human 'O' group RBC cells.

For the phagocytic assay, $10^{7}$ cells of formalinkilled Aeromonas hydrophila were added to $100 \mu \mathrm{l}$ of pooled blood samples in a sterile microplate and incubated for $30 \mathrm{~min}$ at $25^{\circ} \mathrm{C}$ after thorough mixing in the well. Following incubation, the blood-bacteria suspension was mixed gently, and $50 \mu$ of this suspension was smeared on 3 glass slides. After air drying, the smears were fixed in 95\% ethanol, redried and stained with May-Grunwald's Giemsa. The phagocytic cells and phagocytosed bacteria were counted (Park \& Jeong 1996). For the study of serum bactericidal activity, 10 fish from each group were injected with $0.1 \mathrm{ml} \mathrm{kg}^{-1}$ body weight with live virulent $A$. hydrophila suspension $\left(10^{5}\right.$ cells $\left.\mathrm{ml}^{-1}\right)$, and blood samples were collected 10 and 90 min after 
injection. Blood $(100 \mu \mathrm{l})$ was serially diluted and plated in Aeromonas isolation medium (Hi Media). The albumin:globulin ratio (A:G) of the sera was calculated by following the method of Sahoo et al. (1999): the serum samples were analysed for total protein (following the dye-binding method of Bradford 1976 using bovine serum albumin as the standard), for albumin using the bromocresol green method and for globulin by subtracting the albumin value from the total protein value. Finally, the A:G ratio was calculated. Intra-agar lysozyme activity was performed against Micrococcus luteus culture by diluting the blood cells and delivering a drop onto the agar wells. Once the drops were allowed time to absorb into the agar, the wells were incubated upside down for 24 to $48 \mathrm{~h}$ at $37^{\circ} \mathrm{C}$. The wells were then scored for the highest dilution of blood cells capable of lysing the test microbes.

\section{Data analysis}

One-way and 2-way ANOVAs were carried out using the SPSS statistics data package and Ky plot, respectively. Means were compared at the 0.05 and $0.001 \%$ level for 1-way and 2-way ANOVA, respectively.

\section{RESULTS}

\section{Quantitative and qualitative protein analysis of vaccine candidates}

The quantitative protein analysis of different vaccine candidates is outlined in Table 1. An increased protein concentration $(23.54 \mu \mathrm{g})$ was estimated in the WC vaccines. The protein concentration was esti-

Table 1. Total protein quantification $( \pm \mathrm{SD})$ from different types of vaccines for vaccination of Carassius auratus against Aeromonas hydrophila (AHV1). For each vaccine, $\sim 300 \mu \mathrm{g}$ protein antigen was delivered per dose

\begin{tabular}{|lc|}
\hline Vaccine antigen & Total protein \\
\hline $\begin{array}{l}\text { Whole cell vaccine }(\mathrm{WC}) \\
\left(\mu \mathrm{g} \mathrm{m}^{-1} \text { of bacterial pellet }\right)\end{array}$ & $23.54 \pm 0.05$ \\
$\begin{array}{l}\mathrm{ECP} \mathrm{vaccine-1}\left(\mathrm{ECP}_{1}\right) \\
\left(\mu \mathrm{g} \mathrm{ml}^{-1} \text { of broth culture }\right)\end{array}$ & $9.48 \pm 0.32$ \\
$\begin{array}{l}\mathrm{OMP} \mathrm{vaccine-1}\left(\mathrm{OMP}_{1}\right) \\
\left(\mu \mathrm{g} \mathrm{ml}^{-1} \text { of bacterial pellet }\right)\end{array}$ & $10.06 \pm 0.78$ \\
$\begin{array}{l}\text { Biofilm vaccine- }\left(\mathrm{BF}_{2}\right) \\
\left(\mu \mathrm{g} \mathrm{ml}^{-1} \text { of broth culture }\right)\end{array}$ & $9.82 \pm 0.25$ \\
\hline
\end{tabular}

mated as 10.06, 9.82 and $9.48 \mu \mathrm{g}$ in OMP, BF and ECP, respectively. For qualitative analysis, numerous polypeptide bands including $\sim 75,65.5,60,55,45$, 43.7, 31.1 and $15.4 \mathrm{kDa}$ were separated in the WC vaccines by SDS PAGE analysis. The bands were 60 , 43.7 and $15.4 \mathrm{kDa}$ in ECP, and 75, 65.5, 45 and $14.7 \mathrm{kDa}$ in OMP. In BF vaccines, numerous bands were separated at molecular weights of $65.5,45,41.6$, 38.6, 29.5 and $22.6 \mathrm{kDa}$ (Fig. 2).

\section{Growth parameters during the vaccination experiment}

The weight gain (mg) and SGR (\%) were calculated after 25 and $50 \mathrm{dpv}$ with Aeromonas hydrophila challenge, and the results are given in Table 2 . The weight gain recorded in the control group was $0.45 \mathrm{mg}$, whereas the WC had a significantly decreased $(\mathrm{p}<0.05)$ gain of $0.33 \mathrm{mg}$ at $25 \mathrm{dpv}$. The experimental groups significantly $(p<0.05)$ differed in weight gains of $0.23,0.57,0.43,0.44,0.36$ and $0.45 \mathrm{mg}$ in $\mathrm{WC}_{1} \mathrm{ECP}_{1}, \mathrm{ECP}_{2}, \mathrm{OMP}_{1}, \mathrm{OMP}_{2}, \mathrm{BF}_{1}$ and $\mathrm{BF}_{2}$, respectively. We observed the $50 \mathrm{dpv}$ treatment, as well as a minimum and maximum weight gain of 0.89 and $1.32 \mathrm{mg}$, which differed significantly $(\mathrm{p}<0.05)$. An SGR of $5.53 \%$ was observed in the control group. There was little improvement observed for the SGR in other groups, except the $\mathrm{BF}_{2}$ group $(5.56 \%)$ after $25 \mathrm{dpv}$. The other groups achieved the lowest SGR of 2.77 and $3.66 \%$ in $\mathrm{ECP}_{1}$ and $\mathrm{WC}$, respectively. At $50 \mathrm{dpv}$, the SGR was $10.21 \%$ in the control group. It significantly ( $\mathrm{p}<$ 0.05 ) decreased to $8.54 \%$ in $\mathrm{ECP}_{1}$. Conversely, the

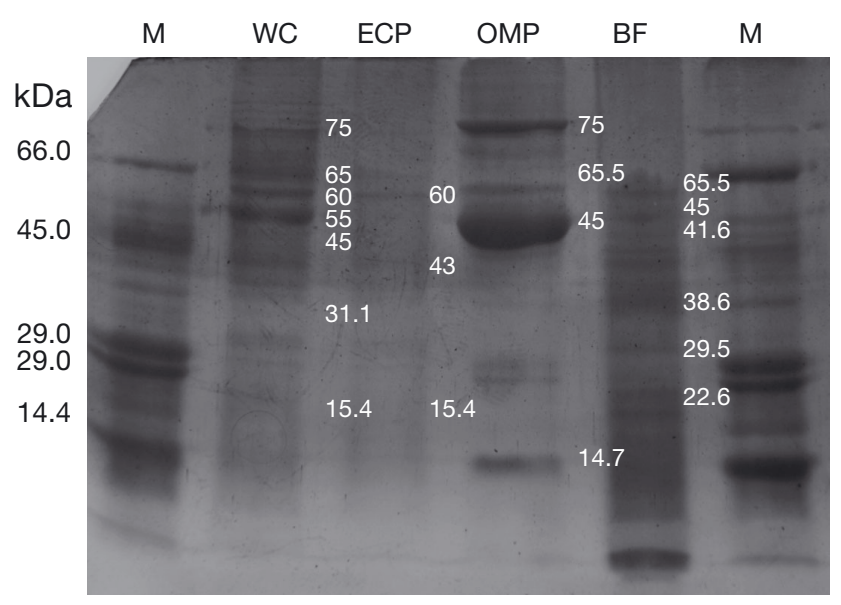

Fig. 2. Qualitative protein profile of different vaccine candidates. M: marker; WC: whole cell protein; ECP: extracellular products; OMP: outer membrane protein; BF: biofilm. Molecular weights are in $\mathrm{kDa}$ 
Table 2. Carassius auratus. Growth parameters $( \pm \mathrm{SD})$ of control vaccinetreated fish $(\mathrm{n}=10$ fish $\times 3$ replicates) on different days post-vaccination (dpv). Within each column, values with the same superscript do not differ significantly from each other (1-way ANOVA; $\mathrm{p}<0.05)$. SGR: specific growth rate. Treatments are described in Fig. 1

\begin{tabular}{|lcccrr|}
\hline \multirow{2}{*}{ Treatment } & \multicolumn{2}{c}{ Weight gain $(\mathrm{mg})$} & & \multicolumn{2}{c|}{ SGR $(\%)$} \\
\cline { 2 - 3 } \cline { 5 - 6 } & $25 \mathrm{dpv}$ & $50 \mathrm{dpv}$ & & $25 \mathrm{dpv}$ & $50 \mathrm{dpv}$ \\
\hline $\mathrm{BC}$ & $0.45 \pm 0.02^{\mathrm{a}}$ & $0.92 \pm 0.02^{\mathrm{a}}$ & & $4.85 \pm 0.03^{\mathrm{a}}$ & $10.22 \pm 0.19^{\mathrm{a}}$ \\
$\mathrm{C}$ & $0.51 \pm 0.01^{\mathrm{b}}$ & $0.89 \pm 0.02^{\mathrm{b}}$ & & $5.53 \pm 0.15^{\mathrm{b}}$ & $10.21 \pm 0.03^{\mathrm{a}}$ \\
$\mathrm{WC}$ & $0.33 \pm 0.02^{\mathrm{c}}$ & $0.92 \pm 0.01^{\mathrm{a}}$ & & $3.66 \pm 0.02^{\mathrm{c}}$ & $10.23 \pm 0.02^{\mathrm{a}}$ \\
$\mathrm{ECP}_{1}$ & $0.23 \pm 0.01^{\mathrm{d}}$ & $0.76 \pm 0.02^{\mathrm{c}}$ & & $2.77 \pm 0.02^{\mathrm{d}}$ & $8.54 \pm 0.03^{\mathrm{b}}$ \\
$\mathrm{ECP}_{2}$ & $0.57 \pm 0.02^{\mathrm{b}}$ & $1.17 \pm 0.01^{\mathrm{d}}$ & & $5.50 \pm 0.02^{\mathrm{b}}$ & $13.2 \pm 0.20^{\mathrm{c}}$ \\
$\mathrm{OMP}_{1}$ & $0.43 \pm 0.01^{\mathrm{a}}$ & $0.96 \pm 0.01^{\mathrm{e}}$ & & $5.23 \pm 0.32^{\mathrm{b}}$ & $10.8 \pm 0.02^{\mathrm{a}}$ \\
$\mathrm{OMP}_{2}$ & $0.44 \pm 0.02^{\mathrm{a}}$ & $1.16 \pm 0.02^{\mathrm{d}}$ & & $5.30 \pm 0.26^{\mathrm{b}}$ & $12.84 \pm 0.04^{\mathrm{c}}$ \\
$\mathrm{BF}_{1}$ & $0.36 \pm 0.02^{\mathrm{c}}$ & $1.11 \pm 0.01^{\mathrm{f}}$ & & $3.73 \pm 0.02^{\mathrm{c}}$ & $12.21 \pm 0.03^{\mathrm{c}}$ \\
$\mathrm{BF}_{2}$ & $0.45 \pm 0.03^{\mathrm{a}}$ & $1.32 \pm 0.02^{\mathrm{g}}$ & & $5.56 \pm 0.25^{\mathrm{b}}$ & $14.5 \pm 0.11^{\mathrm{d}}$ \\
\hline
\end{tabular}

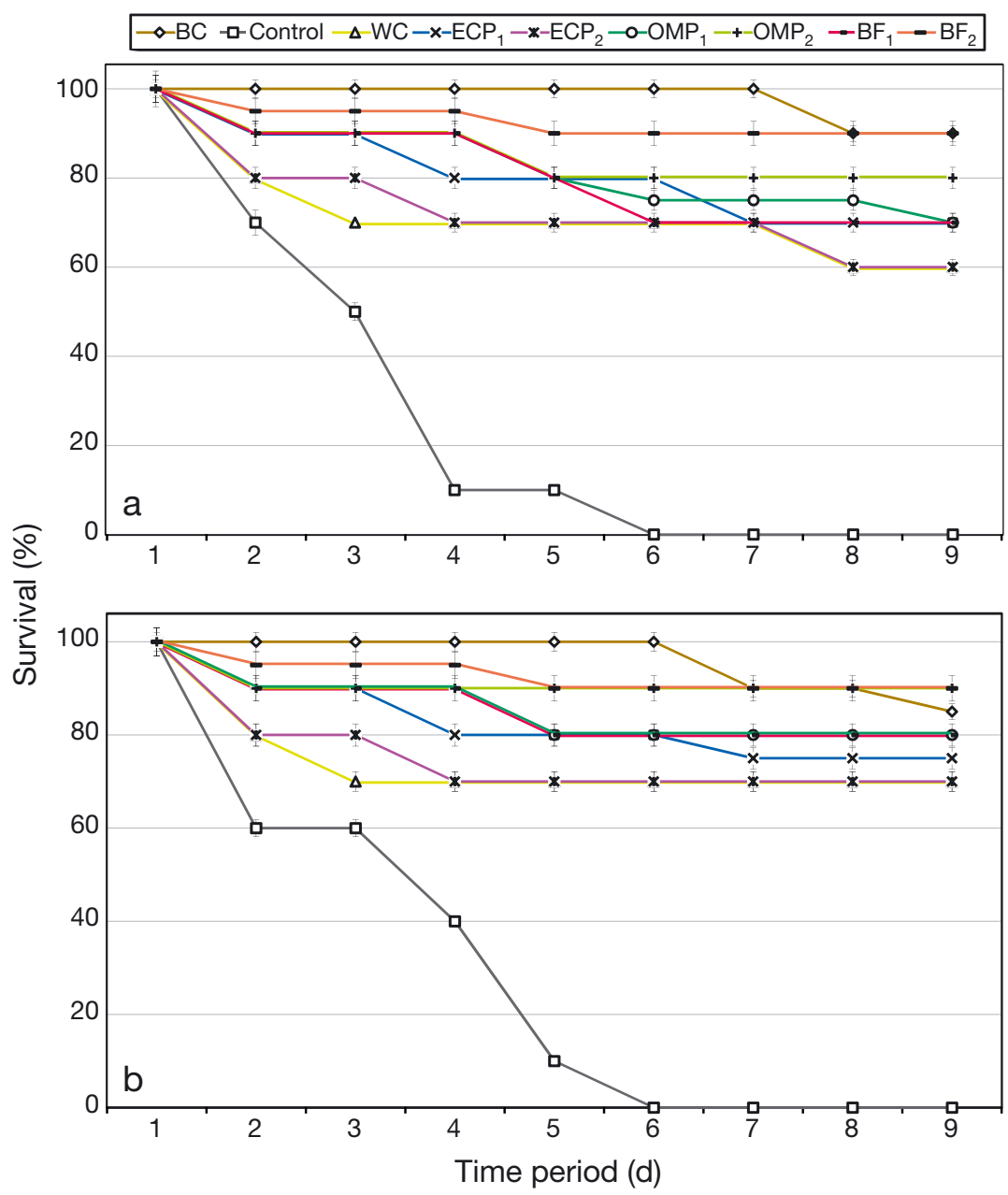

Fig. 3. Carassius auratus. Survival $( \pm \mathrm{SE})$ of fish treated with different types of vaccine with and without adjuvant ( $\mathrm{n}=5$ fish $\times 3$ replicates per treatment) and challenged with AHV1 at (a) $25 \mathrm{~d}$ post-vaccination (dpv; values are significantly different among treatments; $F=31.95$; $\leq 50.001,2$-way ANOVA) and (b) $50 \mathrm{dpv}$ (values are significantly different; $F=29.90 ; \mathrm{p} \leq 0.001 ; 2$-way ANOVA). Treatments are described in Fig. 1
SGR was significantly increased to 12.21, 12.84, 13.2 and $14.5 \%$ in $\mathrm{BF}_{1}$, $\mathrm{OMP}_{2}, \mathrm{ECP}_{2}$ and $\mathrm{BF}_{2}$, respectively.

\section{Survival after 25 and 50 dpv by AHV1 challenge}

All Carassius auratus died (100\% mortality level) within $7 \mathrm{~d}$ as a result of the virulent AHV1 challenge without pre-vaccination after $25 \mathrm{dpv}$. The WC and $\mathrm{ECP}_{2}$ vaccines increased survival to $60 \%$; the $\mathrm{ECP}_{1}, \mathrm{OMP}_{1}$ and $\mathrm{BF}_{1}$ groups showed $70 \%$ survival; and the maximum survival of $90 \%$ was recorded in $\mathrm{BF}_{2}$ groups after the challenge. Two-way ANOVA revealed that the survival values were significantly different from each other $(F=31.95 ; \mathrm{p} \leq$ 0.001; Fig. 3a). The same level of survival was reflected in the vaccinetreated groups after the challenge. Immunoadjuvant-treated OMP and BF groups had the highest survival rate compared to the ECP groups. Two-way ANOVA revealed that the survival values were significantly different from each other $(F=29.90$; $\leq 0.001$; Fig. $3 b)$.

\section{Specific bacterial count after 25 and 50 dpv by AHV1 challenge}

A total Aeromonas sp. count was performed for the specific media for blood and muscle of the challenged Carassius auratus after 25 and $50 \mathrm{dpv}$ (Table 3). A heavier Aeromonas sp. load $\left(4.3 \times 10^{5} \mathrm{cfu} \mathrm{m}^{-1}\right)$ was observed in the blood of the control fish in comparison to the muscle $\left(3.9 \times 10^{5} \mathrm{cfu}\right.$ $\mathrm{g}^{-1}$ ). The vaccines helped to decrease the load in blood. The minimal loads observed were $1.4 \times 10^{2}$ and $1.6 \times 10^{2}$ cfu $\mathrm{ml}^{-1}$ in $\mathrm{OMP}_{2}$ and $\mathrm{BF}_{2}$ groups, respectively, after $25 \mathrm{dpv}$. The same observations were also made for the muscle. A decreased load was observed after $50 \mathrm{dpv}$ in both blood and muscle. The load was $1.1 \times 10^{2}$ and 0.5 $\times 10^{2} \mathrm{cfu} \mathrm{g}^{-1}$ in $\mathrm{OMP}_{2}$ and $\mathrm{BF}_{2}$ groups, respectively, in muscle. 
Table 3. Carassius auratus. Specific Aeromonas count (colony-forming units [cfu], \pm SD) after 25 and 50 d post-vaccination $(\mathrm{dpv})$ in fish ( $\mathrm{n}=5$ fish $\times 3$ replicates) after challenge with AVH1. Treatments are described in Fig. 1

\begin{tabular}{|c|c|c|c|c|}
\hline \multirow[t]{2}{*}{ Treatment } & \multicolumn{2}{|c|}{-Blood $\left(\mathrm{cfu} \mathrm{ml}{ }^{-1}\right)$} & \multicolumn{2}{|c|}{ - Muscle (cfu g $\left.{ }^{-1}\right)$} \\
\hline & $25 \mathrm{dpv}$ & $50 \mathrm{dpv}$ & $25 \mathrm{dpv}$ & $50 \mathrm{dpv}$ \\
\hline $\mathrm{BC}$ & $1.3 \times 10^{1} \pm 0.01 \times 10^{1}$ & $1.3 \times 10^{1} \pm 0.01 \times 10^{1}$ & $1.9 \times 10^{1} \pm 0.10 \times 10^{1}$ & $1.9 \times 10^{1} \pm 0.10 \times 10^{1}$ \\
\hline $\mathrm{C}$ & $4.3 \times 10^{5} \pm 0.06 \times 10^{1}$ & $5.7 \times 10^{5} \pm 0.03 \times 10^{1}$ & $3.9 \times 10^{5} \pm 0.12 \times 10^{1}$ & $4.3 \times 10^{5} \pm 0.20 \times 10^{1}$ \\
\hline WC & $2.3 \times 10^{4} \pm 0.20 \times 10^{1}$ & $3.6 \times 10^{4} \pm 0.50 \times 10^{1}$ & $1.9 \times 10^{4} \pm 0.26 \times 10^{1}$ & $1.5 \times 10^{3} \pm 0.40 \times 10^{1}$ \\
\hline $\mathrm{ECP}_{1}$ & $2.3 \times 10^{3} \pm 0.20 \times 10^{1}$ & $5.1 \times 10^{3} \pm 0.10 \times 10^{1}$ & $2.4 \times 10^{3} \pm 0.20 \times 10^{1}$ & $2.6 \times 10^{2} \pm 0.40 \times 10^{1}$ \\
\hline $\mathrm{ECP}_{2}$ & $1.6 \times 10^{3} \pm 0.11 \times 10^{1}$ & $5.5 \times 10^{3} \pm 0.70 \times 10^{1}$ & $2.1 \times 10^{3} \pm 0.13 \times 10^{1}$ & $1.1 \times 10^{2} \pm 0.30 \times 10^{1}$ \\
\hline $\mathrm{OMP}_{1}$ & $2.6 \times 10^{2} \pm 0.18 \times 10^{1}$ & $4.7 \times 10^{2} \pm 0.11 \times 10^{1}$ & $2.7 \times 10^{2} \pm 0.15 \times 10^{1}$ & $1.3 \times 10^{2} \pm 0.50 \times 10^{1}$ \\
\hline $\mathrm{OMP}_{2}$ & $1.4 \times 10^{2} \pm 0.10 \times 10^{1}$ & $3.7 \times 10^{2} \pm 0.12 \times 10^{1}$ & $1.2 \times 10^{2} \pm 0.10 \times 10^{1}$ & $1.1 \times 10^{2} \pm 0.30 \times 10^{1}$ \\
\hline $\mathrm{BF}_{1}$ & $2.6 \times 10^{3} \pm 0.20 \times 10^{1}$ & $3.5 \times 10^{3} \pm 0.40 \times 10^{1}$ & $2.4 \times 10^{3} \pm 0.01 \times 10^{1}$ & $1.4 \times 10^{2} \pm 0.03 \times 10^{1}$ \\
\hline $\mathrm{BF}_{2}$ & $1.6 \times 10^{2} \pm 0.06 \times 10^{1}$ & $1.05 \times 10^{2} \pm 0.01 \times 10^{1}$ & $1.4 \times 10^{2} \pm 0.14 \times 10^{1}$ & $0.5 \times 10^{2} \pm 0.50 \times 10^{1}$ \\
\hline
\end{tabular}

Table 4. Carassius auratus. Biochemical parameters $( \pm \mathrm{SD})$ of vaccine-treated fish $(\mathrm{n}=10$ fish $\times 3$ replicates) after 25 and $50 \mathrm{~d}$ post-vaccination (dpv) and after challenge with AVH1. Within each column, values with the same superscript do not differ significantly from each other $(1$-way ANOVA $;$ p < 0.05). Treatments are described in Fig. 1

\begin{tabular}{|c|c|c|c|c|c|c|}
\hline \multirow{2}{*}{ Treatment } & \multicolumn{2}{|c|}{ Serum albumin $\left(\mu \mathrm{g} \mathrm{ml}^{-1}\right)$} & \multicolumn{2}{|c|}{ Serum globulin $\left(\mu \mathrm{g} \mathrm{ml}^{-1}\right)$} & \multicolumn{2}{|c|}{ Serum protein $\left(\mu \mathrm{g} \mathrm{ml}^{-1}\right)$} \\
\hline & $25 \mathrm{dpv}$ & $50 \mathrm{dpv}$ & $25 \mathrm{dpv}$ & $50 \mathrm{dpv}$ & $25 \mathrm{dpv}$ & $50 \mathrm{dpv}$ \\
\hline $\mathrm{BC}$ & $221.4 \pm 0.12^{\mathrm{a}}$ & $238.5 \pm 0.05^{\mathrm{a}}$ & $218.2 \pm 0.10^{\mathrm{a}}$ & $224.3 \pm 0.15^{\mathrm{a}}$ & $424.1 \pm 0.11^{\mathrm{a}}$ & $465.5 \pm 0.15^{\mathrm{a}}$ \\
\hline $\mathrm{C}$ & $239.3 \pm 0.13^{\mathrm{b}}$ & $242.3 \pm 0.20^{\mathrm{a}}$ & $208.3 \pm 0.05^{b}$ & $198.3 \pm 0.05^{\mathrm{b}}$ & $436.4 \pm 0.12^{\mathrm{b}}$ & $455.1 \pm 0.15^{\mathrm{b}}$ \\
\hline WC & $252.4 \pm 0.10^{\mathrm{c}}$ & $259.3 \pm 0.05^{\mathrm{b}}$ & $214.4 \pm 0.15^{\mathrm{c}}$ & $218.6 \pm 0.12^{\mathrm{c}}$ & $452.4 \pm 0.03^{\mathrm{c}}$ & $464.4 \pm 0.11^{\mathrm{a}}$ \\
\hline $\mathrm{ECP}_{1}$ & $251.5 \pm 0.11^{\mathrm{c}}$ & $258.6 \pm 0.05^{\mathrm{b}}$ & $230.3 \pm 0.13^{\mathrm{d}}$ & $239.3 \pm 0.15^{\mathrm{d}}$ & $443.4 \pm 0.20^{\mathrm{d}}$ & $480.4 \pm 0.10^{c}$ \\
\hline $\mathrm{ECP}_{2}$ & $262.3 \pm 0.12^{\mathrm{d}}$ & $247.6 \pm 0.15^{\mathrm{c}}$ & $232.4 \pm 0.05^{\mathrm{e}}$ & $230.5 \pm 0.05^{\mathrm{e}}$ & $460.4 \pm 0.10^{\mathrm{e}}$ & $487.4 \pm 0.10^{\mathrm{C}}$ \\
\hline $\mathrm{OMP}_{1}$ & $264.6 \pm 0.11^{\mathrm{d}}$ & $271.5 \pm 0.10^{\mathrm{d}}$ & $233.5 \pm 0.10^{f}$ & $242.4 \pm 0.12^{\mathrm{f}}$ & $486.2 \pm 0.25^{\mathrm{f}}$ & $490.7 \pm 0.16^{\mathrm{e}}$ \\
\hline $\mathrm{OMP}_{2}$ & $268.6 \pm 0.20^{\mathrm{e}}$ & $275.6 \pm 0.25^{\mathrm{d}}$ & $236.6 \pm 0.15^{\mathrm{f}}$ & $240.5 \pm 0.15^{\mathrm{d}}$ & $491.6 \pm 0.12^{\mathrm{g}}$ & $494.6 \pm 0.20^{\mathrm{f}}$ \\
\hline $\mathrm{BF}_{1}$ & $252.5 \pm 0.11^{\mathrm{c}}$ & $253.6 \pm 0.15^{\mathrm{b}}$ & $223.6 \pm 0.16^{g}$ & $238.6 \pm 0.12^{\mathrm{d}}$ & $486.1 \pm 0.17^{\mathrm{f}}$ & $488.5 \pm 0.15^{\mathrm{c}}$ \\
\hline $\mathrm{BF}_{2}$ & $259.4 \pm 0.10^{f}$ & $260.5 \pm 0.05^{\mathrm{e}}$ & $235.6 \pm 0.05^{\mathrm{f}}$ & $240.6 \pm 0.20^{\mathrm{d}}$ & $483.5 \pm 0.08^{f}$ & $494.7 \pm 0.10^{f}$ \\
\hline
\end{tabular}

\section{Biochemical parameter changes after 25 and $50 \mathrm{dpv}$}

The biochemical parameters serum albumin, serum globulin and serum protein $\left(\mu \mathrm{g} \mathrm{ml} \mathrm{ml}^{-1}\right)$ were studied in the blood after 25 and $50 \mathrm{dpv}$ following the AHV1 challenge (Table 4). A serum albumin level of $239.3 \mu^{-1}$ was noted when no vaccination was given after $25 \mathrm{dpv}$. The level of albumin significantly ( $\mathrm{p}<$ 0.05) increased to 252, 259, 262 and $268{\mu g^{-1}}^{-1 n} \mathrm{WC}$, $\mathrm{BF}_{2}, \mathrm{ECP}_{2}$ and $\mathrm{OMP}_{2}$ groups, respectively. The same significant $(p<0.05)$ differences were observed at $50 \mathrm{dpv}$. A globulin level of $208 \mu \mathrm{g}$ was observed in the control group, whereas the experimental groups had significantly ( $p<0.05$ ) higher levels of globulin:

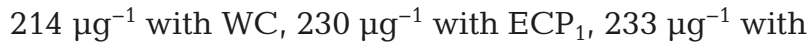

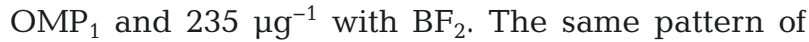
variations was also seen at $50 \mathrm{dpv}$. The experimental groups significantly differed $(p<0.05)$ for the globulin values. The serum protein observed was at 436.4 and $455 \mathrm{\mu g}^{-1}$ in the controls at 25 and $50 \mathrm{dpv}$, respectively. The values significantly $(p<0.05)$ increased in the vaccinated groups. The maximum serum protein

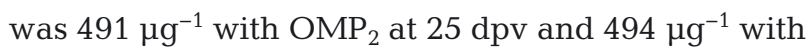
$\mathrm{OMP}_{2}$ and $\mathrm{BF}_{2}$, at $50 \mathrm{dpv}$.

\section{Haematological parameter changes after 25 and $50 \mathrm{dpv}$}

Haemoglobin had a blank control value of $8.43 \mathrm{mg}$ $\mathrm{dl}^{-1}$ with no vaccination when AHV1 challenge was initiated. After the challenge, the haemoglobin level was drastically decreased to $7.17 \mathrm{mg} \mathrm{dl}^{-1}$. The experimental vaccines helped to significantly $(\mathrm{p}<0.05)$ improve the haemoglobin levels to $8.05,8.60,9.24$ and $9.42 \mathrm{mg} \mathrm{dl}^{-1}$ with $\mathrm{ECP}_{2}, \mathrm{OMP}_{1}, \mathrm{OMP}_{2}$ and $\mathrm{BF}$, respectively, after $25 \mathrm{dpv}$. At $50 \mathrm{dpv}$, the haemoglobin level was similar to those at $25 \mathrm{dpv}$. A red blood cell (RBC) count of $0.86\left(\times 10^{6} \mathrm{~mm}^{-3}\right)$ was observed in the control fish after $25 \mathrm{dpv}$, and this significantly $(\mathrm{p}<0.05)$ increased to $1.32,1.34,1.35$ and $1.42\left(\times 10^{6}\right.$ $\mathrm{mm}^{-3}$ ) with $\mathrm{WC}, \mathrm{OMP}_{1}, \mathrm{BF}_{2}$ and $\mathrm{OMP}_{2}$, respectively. At $50 \mathrm{dpv}$, haemoglobin increased to a maximum level of $1.48 \mathrm{mg} \mathrm{dl}^{-1}$ in the $\mathrm{BF}_{2}$ groups due to the 
Table 5. Carassius auratus. Haematological parameters $( \pm \mathrm{SD})$ of vaccinetreated fish ( $\mathrm{n}=10$ fish $\times 3$ replicates per treatment) after 25 and $50 \mathrm{~d}$ postvaccination (dpv) and after challenge with AVH1. Within each column, values with the same superscript do not differ significantly from each other (1-way ANOVA; $\mathrm{p}<0.05)$. Hb: haemoglobin; RBC: red blood cells. Treatments are described in Fig. 1

\begin{tabular}{|c|c|c|c|c|}
\hline \multirow[t]{2}{*}{ Treatment } & \multicolumn{2}{|c|}{$\longrightarrow \mathrm{Hb}\left(\mathrm{mg} \mathrm{dl}^{-1}\right)-$} & \multicolumn{2}{|c|}{$\longrightarrow \mathrm{RBC}\left(\times 10^{6} \mathrm{~mm}^{-3}\right)$} \\
\hline & $25 \mathrm{dpv}$ & $50 \mathrm{dpv}$ & $25 \mathrm{dpv}$ & $50 \mathrm{dpv}$ \\
\hline $\mathrm{BC}$ & $8.43 \pm 0.03^{\mathrm{a}}$ & $8.82 \pm 0.04^{\mathrm{a}}$ & $1.02 \pm 0.050^{\mathrm{a}}$ & $1.05 \pm 0.060^{\mathrm{a}}$ \\
\hline $\mathrm{C}$ & $7.17 \pm 0.02^{\mathrm{b}}$ & $7.66 \pm 0.04^{\mathrm{b}}$ & $0.86 \pm 0.002^{\mathrm{b}}$ & $0.84 \pm 0.004^{\mathrm{b}}$ \\
\hline WC & $7.44 \pm 0.04^{\mathrm{b}}$ & $7.83 \pm 0.02^{\mathrm{b}}$ & $1.32 \pm 0.050^{\mathrm{c}}$ & $1.36 \pm 0.050^{\mathrm{c}}$ \\
\hline $\mathrm{ECP}_{1}$ & $7.72 \pm 0.02^{\mathrm{b}}$ & $7.92 \pm 0.03^{\mathrm{b}}$ & $1.20 \pm 0.003^{\mathrm{d}}$ & $1.26 \pm 0.030^{\mathrm{d}}$ \\
\hline $\mathrm{ECP}_{2}$ & $8.05 \pm 0.03^{\mathrm{C}}$ & $8.17 \pm 0.05^{\mathrm{c}}$ & $1.24 \pm 0.030^{\mathrm{e}}$ & $1.28 \pm 0.020^{\mathrm{d}}$ \\
\hline $\mathrm{OMP}_{1}$ & $8.60 \pm 0.03^{\mathrm{d}}$ & $9.04 \pm 0.04^{\mathrm{d}}$ & $1.34 \pm 0.067^{\mathrm{c}}$ & $1.38 \pm 0.007^{\mathrm{c}}$ \\
\hline $\mathrm{OMP}_{2}$ & $9.24 \pm 0.04^{\mathrm{e}}$ & $9.64 \pm 0.04^{\mathrm{e}}$ & $1.42 \pm 0.090^{\mathrm{f}}$ & $1.57 \pm 0.002^{\mathrm{e}}$ \\
\hline $\mathrm{BF}_{1}$ & $8.83 \pm 0.03^{d}$ & $9.17 \pm 0.02^{\mathrm{d}}$ & $1.24 \pm 0.040^{\mathrm{e}}$ & $1.28 \pm 0.004^{\mathrm{d}}$ \\
\hline $\mathrm{BF}_{2}$ & $9.42 \pm 0.03^{\mathrm{e}}$ & $9.80 \pm 0.01^{\mathrm{e}}$ & $1.35 \pm 0.031^{\mathrm{c}}$ & $1.48 \pm 0.001^{\mathrm{f}}$ \\
\hline
\end{tabular}

\section{Immunological parameter changes after 25 and $50 \mathrm{dpv}$}

The percentage of phagocytic activity showed a significant variance $(\mathrm{p}<0.01)$ between the control and vaccine-treated goldfish following the AHV1 challenge. In the control group, around $18 \%$ of the Aeromonas hydrophila cells were phagocytosed, and the percentage increased significantly $(\mathrm{p}<0.01)$ to $44.1,45.05,46.05$ and $47.08 \%$ in $\mathrm{WC}_{1} \mathrm{BF}_{1}, \mathrm{ECP}_{2}$ and $\mathrm{BF}_{2}$ groups, respectively. After $50 \mathrm{dpv}, \mathrm{WC}$, $\mathrm{OMP}_{2}, \mathrm{BF}_{1}$ and $\mathrm{BF}_{2}$ groups showed significant increases $(\mathrm{p}<0.01)$ in the phagocytic activity to a level of more than $50 \%$ (Fig. 4). The fish serum bactericidal activity for 25 and $50 \mathrm{dpv}$ is shown in

immunoadjuvant effects (Table 5). The haemagglutinin assay revealed that the agglutination took place at a dilution of 1:4 with WC and 1:8 with ECP1, ECP2, $\mathrm{OMP}_{1}$ and $\mathrm{BF}_{1}$, respectively. The immunoadjuvant helped to increase the titre value, and agglutination occurred at the 1:12 dilution level for $\mathrm{OMP}_{2}$ and $\mathrm{BF}_{2}$ (Table 6).
Fig. 5. A serum bactericidal activity of $3.88 \%$ was observed in the control groups, whereas the $\mathrm{ECP}_{1}$, $\mathrm{OMP}_{2}$ and $\mathrm{BF}_{2}$ groups had significantly higher $(\mathrm{p}<$ 0.01 ) serum bactericidal activities of $7.82,11.2$ and $13.4 \%$, respectively, after $25 \mathrm{dpv}$. The fish vaccinated with the immunoadjuvant displayed more than $10 \%$ difference in serum bactericidal activity from the

Table 6. Carassius auratus. In vitro haemoagglutinin assay of vaccine-treated fish blood with human 'O' group red blood cells after 25 and 50 d post-vaccination (dpv) and after challenge with AVH1. +: agglutination occurred; -: agglutination did not occur; +ive: positive; -ive: negative. Treatments are described in Fig. 1

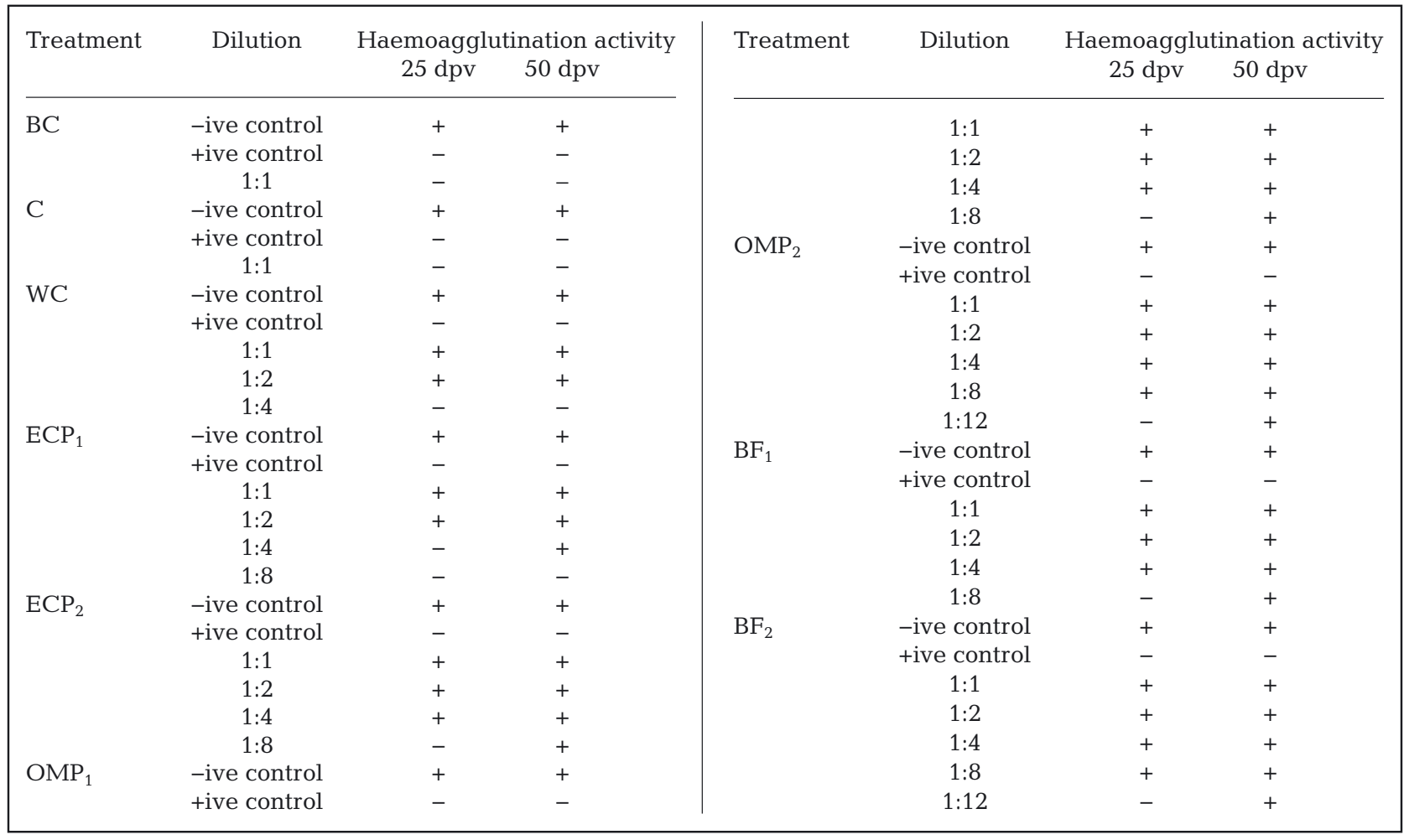




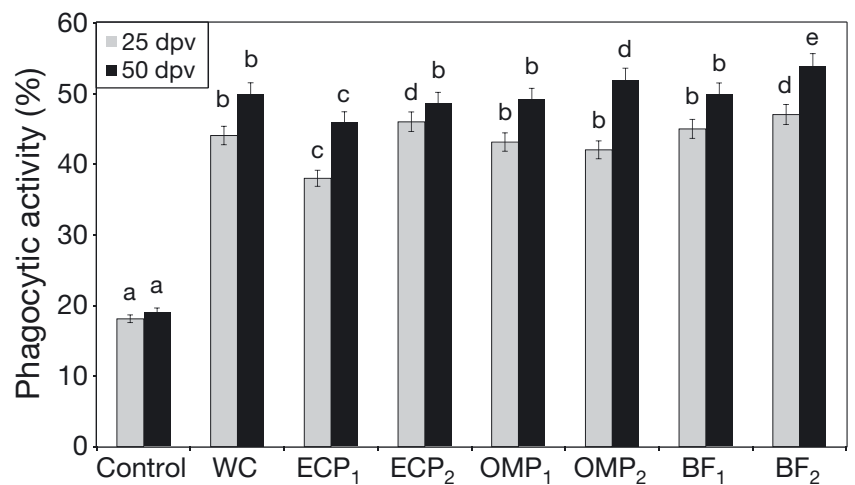

Fig. 4. Carassius auratus. Phagocytic activity $( \pm \mathrm{SE})$ of fish treated with different types of vaccine with and without adjuvant ( $\mathrm{n}=5$ fish $\times 3$ replicates per treatment) and challenged with virulent AHV1 after 25 and $50 \mathrm{~d}$ post-vaccination (dpv). Values with the same superscript do not differ significantly from each other ( $p<0.01$; 1 -way ANOVA). Treatments are described in Fig. 1

control, and were significantly ( $p<0.01)$ different at $50 \mathrm{dpv}$. The A:G ratios were 1.3 and $1.7 \%$ in the control groups at 25 and $50 \mathrm{dpv}$, respectively. These ratios significantly $(\mathrm{p}<0.01)$ increased in the experimental groups, and the maximum ratios of 5.5 and $7.6 \%$, respectively, were recorded in the $\mathrm{BF}_{2}$ groups at 25 and $50 \mathrm{dpv}$ (Fig. 6). The intra-agar lysozyme activity of the blood serum of vaccinated fish performed against AHV1 is given in Table 7 for 25 and $50 \mathrm{dpv}$. The zone of inhibition was found to be $4.59 \mathrm{~mm}$ in the control group at $10^{-1}$ dilution at $25 \mathrm{dpv}$. Two-way ANOVA revealed that the intra-agar lysozyme activity significantly $(F=52.33 ; \mathrm{p} \leq 0.001)$ increased in vaccinated groups when compared to the control group. A similar outcome was reflected at $50 \mathrm{dpv}$. The control group had a $5.44 \mathrm{~mm}$ zone of inhibition. This zone significantly $(F=31.78 ; \mathrm{p} \leq 0.001)$ increased to $12.67,14.77,15.7$ and $18.77 \mathrm{~mm}$ with $\mathrm{WC}_{1} \mathrm{BF}_{2}, \mathrm{ECP}_{1}$ and $\mathrm{OMP}_{2}$, respectively, in $10^{-1}$ dilutions.

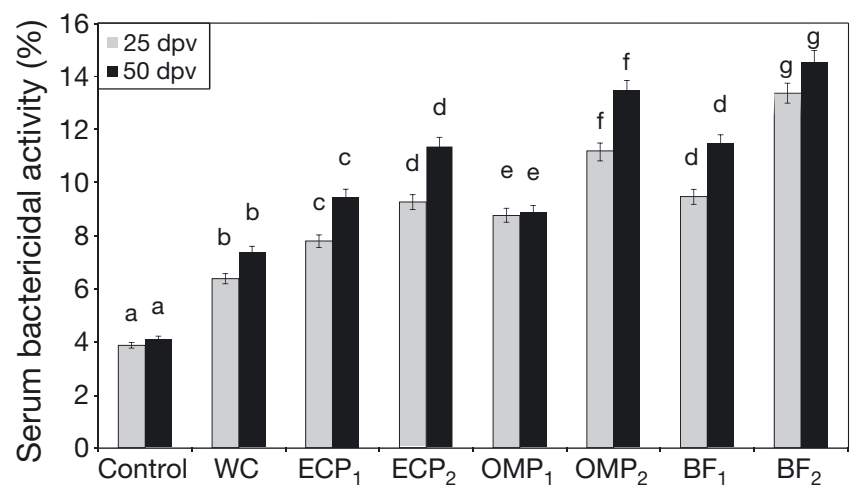

Fig. 5. Carassius auratus. Serum bactericidal activity $( \pm \mathrm{SE})$ of fish treated with different types of vaccine with and without adjuvant ( $\mathrm{n}=5$ fish $\times 3$ replicates per treatment) and challenged with virulent AHV1 after 25 and $50 \mathrm{~d}$ post-vaccination (dpv). Values with the same superscript do not differ significantly from each other ( $p<0.01$; 1 -way ANOVA). Treatments are described in Fig. 1

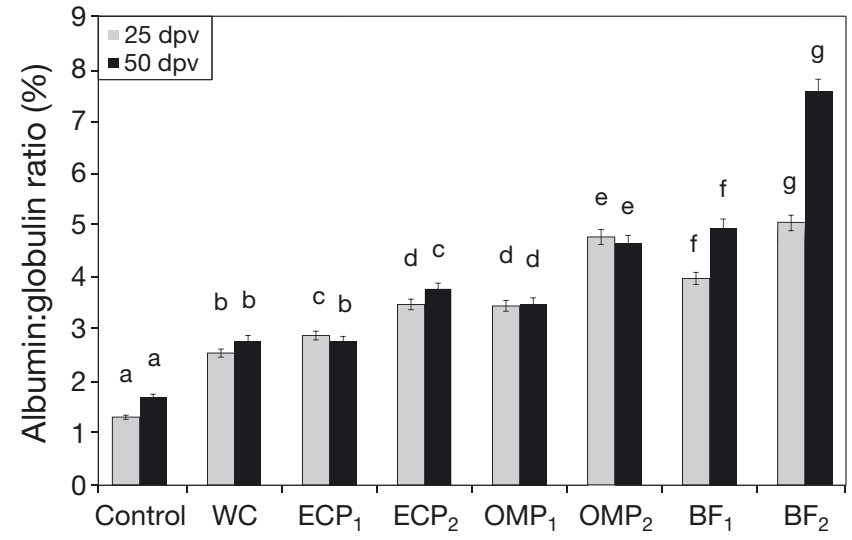

Fig. 6. Carassius auratus. Albumin:globulin ratio $( \pm \mathrm{SE})$ of fish treated with different types of vaccine with and without adjuvant ( $\mathrm{n}=5$ fish $\times 3$ replicates per treatment) and challenged with virulent AHV1 after 25 and $50 \mathrm{~d}$ post-vaccine (dpv). Values with the same superscript do not differ significantly from each other $(\mathrm{p}<0.01$; 1 -way ANOVA). Treatments are described in Fig. 1

Table 7. Carassius auratus. Zone formation $(\mathrm{mm}, \pm \mathrm{SD})$ of intra-agar lysozyme activity of the blood serum of fish treated with vaccines $(\mathrm{n}=10 \mathrm{fish} \times 3$ replicates per treatment) and challenged with AHV1 after 25 and $50 \mathrm{~d}$ post-vaccination (dpv). All values are significantly different among treatments (2-way ANOVA: $F=52.33$ [25 dpv]; $F=31.78$ [50 dpv]; $p \leq 0.001$ ). Treatments are described in Fig. 1

\begin{tabular}{|c|c|c|c|c|c|c|}
\hline \multirow{2}{*}{ Treatment } & \multicolumn{2}{|c|}{$-10^{-1}$ dilution -} & \multicolumn{2}{|c|}{$-10^{-2}$ dilution } & \multicolumn{2}{|c|}{$-10^{-3}$ dilution } \\
\hline & $25 \mathrm{dpv}$ & $50 \mathrm{dpv}$ & $25 \mathrm{dpv}$ & $50 \mathrm{dpv}$ & $25 \mathrm{dpv}$ & $50 \mathrm{dpv}$ \\
\hline $\mathrm{C}$ & $4.59 \pm 0.03$ & $5.44 \pm 0.04$ & $4.81 \pm 0.04$ & $4.33 \pm 0.10$ & $2.55 \pm 0.03$ & $3.63 \pm 0.07$ \\
\hline WC & $12.08 \pm 0.12$ & $12.67 \pm 0.08$ & $12.02 \pm 0.15$ & $11.50 \pm 0.03$ & $8.34 \pm 0.02$ & $9.85 \pm 0.01$ \\
\hline $\mathrm{ECP}_{1}$ & $14.26 \pm 0.05$ & $15.70 \pm 0.11$ & $14.38 \pm 0.01$ & $13.87 \pm 0.01$ & $8.07 \pm 0.03$ & $8.57 \pm 0.08$ \\
\hline $\mathrm{ECP}_{2}$ & $14.83 \pm 0.05$ & $15.48 \pm 0.15$ & $15.36 \pm 0.12$ & $14.85 \pm 0.12$ & $9.28 \pm 0.01$ & $9.77 \pm 0.01$ \\
\hline $\mathrm{OMP}_{1}$ & $15.46 \pm 0.05$ & $17.46 \pm 0.15$ & $11.76 \pm 0.02$ & $11.26 \pm 0.01$ & $8.24 \pm 0.02$ & $9.45 \pm 0.01$ \\
\hline $\mathrm{OMP}_{2}$ & $17.84 \pm 0.02$ & $18.77 \pm 0.01$ & $16.18 \pm 0.08$ & $15.67 \pm 0.04$ & $10.24 \pm 0.01$ & $11.75 \pm 0.06$ \\
\hline $\mathrm{BF}_{1}$ & $13.46 \pm 0.01$ & $14.05 \pm 0.02$ & $13.07 \pm 0.01$ & $12.56 \pm 0.08$ & $7.36 \pm 0.14$ & $8.17 \pm 0.12$ \\
\hline $\mathrm{BF}_{2}$ & $14.25 \pm 0.03$ & $14.77 \pm 0.02$ & $14.37 \pm 0.12$ & $13.86 \pm 0.02$ & $9.25 \pm 0.04$ & $10.76 \pm 0.01$ \\
\hline
\end{tabular}




\section{DISCUSSION}

During the last $20 \mathrm{yr}$, vaccination has been established as a preventive method against various bacterial pathogens in aquaculture (Sommerset et al. 2005). Our work concentrated on traditional vaccine candidates, including $\mathrm{WC}$ and $\mathrm{ECP}$, and the modern approaches of OMP and BF vaccines with a safe herbal adjuvant. A higher amount of total protein $(23.54 \mu \mathrm{g})$ is present in the $\mathrm{WC}$ vaccine due to the numerous polypeptides ranging in molecular weight from 15 to $65 \mathrm{kDa}$. The WC vaccines helped to improve fish survival and other parameters when compared to the control. Aeromonas hydrophila aroA is an attenuated strain that has been assessed as a live vaccine in rainbow trout Oncorhynchus mykiss, which showed higher and long-lasting immunity (Vivas et al. 2005). The elicitation of high and long-lasting immune responses by live bacterial vaccines has been related to the persistence of the vaccine in the tissues (Marsden et al. 1996). The ECP of AHV1 consists of a few polypeptides ranging from 30 to $45 \mathrm{kDa}$ and has higher virulence. In our previous study (Thanga Viji et al. 2011), the ECP of this strain had strong haemolytic and proteolytic activities and caused $100 \%$ mortality in Carassius auratus. A. hydrophila isolated from oyster produced higher levels of toxins such as haemolysin and cytotoxin (Tsai et al. 1997). Nieto \& Ellis (1991) fractionated ECP of A. hydrophila to produce a purified polypeptide toxin of $15.5 \mathrm{kDa}$ which was 300 times more toxic than the crude ECP. OMP contains 4 polypeptides ranging from 15 to $65 \mathrm{kDa}$, and the $\mathrm{BF}$ contains numerous protein bands. In our previous work (Thanga Viji et al. 2012), a prominent OMP with a molecular weight of $37 \mathrm{kDa}$ was extracted from 3 different strains of $A$. hydrophila. The OMPs of $A$. hydrophila are rather heterogeneous in most of the strains but a $36 \mathrm{kDa}$ protein is common to most strains. Khushiramani et al. (2008) isolated 3 to 4 high-intensity OMP bands from 40 strains of $A$. hydrophila that ranged from 25 to $45 \mathrm{kDa}$. Asha et al. (2004) studied the expression of antigenic BF from $A$. hydrophila and identified about 15 protein bands that ranged from 10 to $15 \mathrm{kDa}$.

The SGR as well as the weight gain was not reflected after $25 \mathrm{dpv}$ in vaccinated Carassius auratus, whereas the groups treated with vaccine plus immunoadjuvant achieved significant growth after $50 \mathrm{dpv}$. This may be the immune boosting effect of immunoadjuvants, and the herbal immunoadjuvantlike Asparagus racemosus helps to increase the antigen uptake and thus improves the immune system. Saponin-based adjuvants have the ability to modulate the cell-mediated immune system as well as to enhance antibody production and have the advantage that only a low dose is needed for adjuvant activity (Cohen \& Bioterrorism 2001). Relative to the vaccines which were delivered alone, the booster dose helped to reduce the cumulative mortality to $10 \%$ after Day 10 following the challenge in the present study. Recently, attention has been given to immunoproteomic vaccines such as bacterial OMP (Maji et al. 2006) and BF vaccines (Azad et al. 1999) to confer immune responses against bacterial and viral pathogens. The OMP vaccines helped to decrease the cumulative mortality to $30 \%$ and the OMP with adjuvant to $20 \%$ after Aeromonas hydrophila challenge (Thanga Viji et al. 2012). Fang et al. (2000) showed significant protection against 2 isolates of $A$. hydrophila in blue gourami Trichogaster trichopterus (75 and 87.5\% relative percent survival, RPS) immunized with a recombinant $43 \mathrm{kDa}$ OMP. The $37 \mathrm{kDa}$ OMP of $A$. hydrophila was immunogenic in rohu carp (Khushiramani et al. 2007). Among the different types of vaccine treatment in the present study, the $C$. auratus group treated with OMP and BF with adjuvant showed higher immunogenic performance including survival and decreased specific bacterial load. Similarly, C. auratus gibelio vaccinated with formalinkilled cells of $A$. hydrophila with the adjuvant Apis mellifera propolis showed an enhanced RPS of $67.8 \%$ after challenge with $A$. hydrophila (Chu 2006). The adjuvant could enhance immune response by increasing the activity of leukocytes and plasmocytes as well as by speeding up the production of specific antibodies (Williams et al. 1989).

The immunoadjuvant helps to improve albumin, globulin and protein levels in the serum levels when combined with ECP, OMP and BF. Herbal immunostimulants such as Lonicera japonica and Ganoderma lucidum also help to increase the immunoglobulin level in Oreochromis niloticus against Aeromonas hydrophila challenge. Rairakhwada et al. (2007) found that the globulin content was significantly enhanced in levan-fed common carp fingerlings. Misra et al. (2006) reported that total serum protein content increased significantly in fish fed with dietary doses of $\beta$-glucan.

In Carassius auratus, haemoglobin $\left(9.79 \mathrm{~g} \mathrm{dl}^{-1}\right)$ and haematocrit $(28.90 \%)$ values improved compared to the controls (Harikrishnan \& Balasundaram 2008). In the present study, the level of haemoglobin and RBC increased compared to the control groups, and the maximum levels were increased in the adjuvanttreated groups. Sahu et al. (2007) reported that WBC and RBC counts were higher in Labeo rohita finger- 
lings fed Mangifera indica kernel when compared to controls. In our experiment, the fish were also treated without vaccines, and low levels of RBC $\left(0.8 \times 10^{6} \mathrm{~mm}^{-3}\right)$ were recorded after 25 and $50 \mathrm{dpv}$. The low level of RBC caused losses of body fluids and oxygen carrying capacity, which eventually led to mortality. In infected untreated fish, decreased RBC, haematocrit and haemoglobin concentrations indicated that RBCs were destroyed by leukocytosis with subsequent erythroblastosis (Hawk et al. 1954). The haemoagglutinin assay in our work revealed that the vaccinated groups react even at the lowest dilution, and the adjuvant-treated groups were agglutinated at dilutions of 1:12 in $\mathrm{ECP}_{2}, \mathrm{OMP}_{2}$ and $\mathrm{BF}_{2}$. This may be due to the increased antibody production including the albumin, globulin and protein levels in the blood serum of the adjuvant-treated groups. The immunoadjuvant potential of Asparagus racemosus aqueous root extract was evaluated in experimental animals immunized with diphtheria, tetanus, pertussis (DTP) vaccine; the immunized animals had a significantly increased level in antibody titres against Bordetella pertussis challenge (Gautman et al. 2004).

The prolonged period of vaccination (50 d in the present study) is responsible for higher immunological improvement compared to the shorter period (25 d) of vaccination. The immunological parameters of phagocytosis serum bactericidal activity, A:G ratio and intra-agar lysozyme activity were increased by the vaccines. The immunoadjuvant helped to significantly enhance the immunological activities along with the vaccines. The phagocytic activity was also increased in experimental groups as compared to the control fish. The immunoadjuvant helped to enhance the phagocytic activity over 1.5 times. The BF vaccines with immunoadjuvants were more highly immunogenic than other vaccine preparations. The BF antigens had enhanced uptake and longer retention compared to that of free-cell vaccine (Azad et al. 1997). The extracts of 4 Chinese herbs (Rheum officinale, Andrographis paniculata, Isatis indigotica, Lonicera japonica) increased phagocytosis of white blood cells of crucian carp (Chen \& Kusuda 1996). Tatefuji et al. (1996) reported that the compounds of propolis could enhance macrophage mobility and spreading. Due to the active nature of saponins, the herbal immunoadjuvant Asparagus racemosus may greatly improve the induction of major histocompatibility complex class I-restricted CD81 cytotoxic T lymphocyte responses.

Azad et al. (2000) administered Aeromonas hydrophila BF vaccine to 3 species of carp (Catla catla, Labeo rohita and Cyprinus carpio) at different doses and for varying periods of time. Among the 3 carp species, catla produced the highest antibody and protective response, followed by rohu and common carp after 15 and $20 \mathrm{dpv}$. In our study, the serum bactericidal activity was increased in the vaccines without adjuvant and increased more than 2 times in the adjuvant-treated groups compared to the control group. The IgY edible antibody, produced with the herbal adjuvant Asparagus racemosus, is a good vaccine candidate for improving serum bactericidal activity against white-spot symdrome virus (WSSV) infection in Penaeus monodon (Kumaran et al. 2010). Herbal immunostimulants also enhanced the serum bactericidal and lysozyme activity against Vibrio harveyi infection in grouper Ephinephelus tauvina (Sivaram et al. 2004, Punitha et al. 2008). The increased A:G ratio in vaccine-treated groups in our study indicated higher immune responses. The highest A:G ratio was observed in immunoadjuvanttreated groups compared to the other groups. The prolonged time post-vaccinations also helped to improve the A:G ratio. The herbal adjuvant $A$. racemosus helped to boost the immune system along with OMP and $\mathrm{BF}$ vaccines. The immunoadjuvant $A$. racemosus in vaccines may activate the antigen-presenting cells (e.g. macrophages) to produce cytokines which can activate lymphocytes producing specific antibodies. Cuesta et al. (2005) investigated the propolis on the innate immune responses of gilthead seabream and found that it has limited immunostimulatory effects. Total lysozyme is a measurable humoral component of the non-specific defence mechanism, and while reports on modulation of lysozyme activity in fishes are rare, increased values have been recorded by various authors after activation of the immune system with immunomodulants (Engstad \& Robertson 1993, Siwicki et al. 1994) and by feeding 4 different Chinese herbs (Rheum officinale, Andrographis paniculata, Isatis indigotica, Lonicera japonica; Chen \& Kusuda 1996). The intra-agar lysozyme activity was higher in the vaccinated groups, and the maximum level observed showed a 2-fold increase in the immunoadjuvant plus BF-treated groups. The herbal adjuvant $A$. racemosus enhanced lysozyme activity in tilapia fed low $(0.1 \%)$ and medium $(0.5 \%)$ doses of herbs (Yin et al. 2006). A. racemosus was also responsible for higher lysozyme activity, along with Aeromonas hydrophila OMP in C. auratus (Thanga Viji et al. 2012) and higher immune responses in P. monodon treated with anti-WSSV IgY, which was produced from $A$. racemosus extracts (Kumaran et al. 2010). We conclude that the herbal immunoadjuvant A. racemosus improved the immunoadjuvant activity 
of different vaccines (WC, ECP, OMP and BF) and improved the immunological enhancement in $C$. auratus. A. racemosus was found to be highly promising as a safe and low-cost adjuvant in fish vaccines against Aeromonas sp. infection.

Acknowledgements. V.T.V. gratefully acknowledges the UGC-Networking Resource Centre in Biological Sciences (NRCBS), School of Biological Sciences, Madurai Kamaraj University, India. We dedicate this article to our late Professor, M. Peter Marian, Former Head, Centre for Marine Science and Technology, Manonmaniam Sundaranar University, India.

\section{LITERATURE CITED}

Adams A, Auchinachie N, Bundy A, Tatner MF, Horne MT (1988) The potency of adjuvanted injected vaccines in rainbow trout (Salmo gairdneri Richardson) and bath vaccines in Atlantic salmon (Salmo salar L.) against furunculosis. Aquaculture 69:15-26

Andrews C (1990) The ornamental fish trade and fish conservation. J Fish Biol 37:53-59

> Asha A, Nayaka DK, Shankara KM, Mohan CV (2004) Antigen expression in biofilm cells of Aeromonas hydrophila employed in oral vaccination of fish. Fish Shellfish Immunol 16:429-436

Azad IS, Shankar KM, Mohan CV (1997) Evaluation of an Aeromonas hydrophila biofilm for oral vaccination of carp. In: Flegel TW, Macrae IH (eds) Diseases in Asian aquaculture III. Fish Health Section, Asian Fisheries Society, Manila, p 181-186

> Azad IS, Shankar KM, Mohan CV, Kalita B (1999) Biofilm vaccine of Aeromonas hydrophila-standardization of dose and duration for oral vaccination of carps. Fish Shellfish Immunol 9:519-528

Azad IS, Shankar KM, Mohan CV, Kalita B (2000) Uptake and processing of biofilm and free-cell vaccines of Aeromonas hydrophila in Indian major carps and common carp following oral vaccination - antigen localization by a monoclonal antibody. Dis Aquat Org 43: 103-108

Beaune J, Llorca G, Gonin A, Bran Y, Fleurette J, Neidhart JP (1978) Phlegmon nécrotique de la main, point de départ d'une septicémie due à Aeromonas hydrophila. Démonstration de l'origine ichtyologique de l'infection. Nouv Presse Med 7:1206-1207

Bradford MM (1976) A rapid and sensitive method for the quantitation of microgram quantities of protein utilizing the principle of protein-dye binding. Anal Biochem 72: 248-254

Chen CF, Kusuda RA (1996) Preliminary study on the adjuvant activity of henbane in oral vaccination of grass carp (Ctenopharyngodon idellus). J Huazhong Agric Univ 15: 157-161

> Chu W (2006) Adjuvant effect of propolis on immunization by inactivated Aeromonas hydrophila in carp (Carassius auratus gibelio). Fish Shellfish Immunol 21:113-117

Cohen J, Bioterrorism ME (2001) Vaccines for biodefense: a system in distress. Science 294:498-501

Costa AB (2004) Estratégias para o estudo de bactérias potencialmente patogênicas na piscicultura. In: Cyrino JEP, Urbinati EC, Fracalossi DM, Castagnolli N (eds) Tópicos especiais em piscicultura de água doce tropical intensiva. Tec Art, São Paulo, p 387-404

Cuesta A, Rodri A, Esteban MA, Meseguer J (2005) In vivo effects of propolis, a honeybee product, on gilthead sea bream innate immune responses. Fish Shellfish Immunol 18:71-80

> Daskalov H (2006) The importance of Aeromonas hydrophila in food safety. Food Contr 17:474-483

Ebanks RO, Dacancy A, Goguen M, Pinto DM, Ross NW (2004) Differential proteomic analysis of Aeromonas hydrophila outer membrane proteins in response to low iron and in vivo growth conditions. Proteomics 4: 1074-1085

Engstad RE, Robertson B (1993) Recognition of yeast wall glucan by Atlantic salmon (Salmo salar). Dev Comp Immunol 17:319-330

> Fang HM, Ling KC, Ge R, Sin M (2000) Enhancement of protective immunity in blue gourami, Trichogaster trichopterrus (Pallas), against Aeromonas hydrophila and Vibrio anguillarum by $A$. hydrophila major adhesion. J Fish Dis 23:137-145

Gautam M, Diwanay S, Gairola S, Shinde Y, Patki P, Patwardhan B (2004) Immunoadjuvant potential of Asparagus racemosus aqueous extract in experimental system. J Ethnopharmacol 91:251-255

> Harikrishnan R, Balasundaram C (2008) In vitro and in vivo studies of the use of some medicinal herbals against the pathogen Aeromonas hydrophila in goldfish. J Aquat Anim Health 20:165-176

Hawk PB, Oser BL, Summerson WH (1954) Practical physiological chemistry. The Blakiston Company, Philadelphia, PA

Hendricks LJ (1952) Erythrocytes counts and hemoglobin determinations for two species of sucker, genus Catostomus, from Colorado. Copeia 1952:265-266

Kensil CR (1996) Saponins as vaccine adjuvants. Crit Rev Ther Drug Carrier Syst 13:1-55

> Khushiramani R, Girisha SK, Karunasagar I, Karunasagar I (2007) Cloning and expression of an outer membrane protein ompTS of Aeromonas hydrophila and study of immunogenicity in fish. Protein Expr Purif 51:303-307

Khushiramani R, Girisha SK, Bhowmick PP, Karunasagark I (2008) Prevalence of different outer membrane proteins in isolates of Aeromonas species. World J Microbiol Biotechnol 24:2263-2268

Kumaran T, Babu MM, Selvaraj T, Dhas SA, Citarasu T (2010) Production of anti WSSV IgY edible antibody using herbal immunoadjuvant Asparagus racemosus and its immunological influence against WSSV infection in Penaeus monodon. J Aquacult Feed Sci Nutr 2:1-5

Laemmli UK (1970) Cleavage of structural proteins during assembly of the head of bacteriophage T4. Nature 227: 680-685

Lowry OH, Rosenberough NJ, Farr AL, Randal RJ (1951) Protein measurement with folinphenol reagent. J Biochem 193:265-275

Maji S, Mali P, Joardar SN (2006) Immunoreactive antigens of the outer membrane protein of Aeromonas hydrophila, isolated from goldfish, Carassius auratus (Linn.). Fish Shellfish Immunol 20:462-473

> Marsden MJ, Vaughan LM, Foster TJ, Secombes CJ (1996) A live (Delta aro A) Aeromonas salmonicida vaccine for furunculosis preferentially stimulates $\mathrm{T}$-cell responses 
relative to B-cell responses in rainbow trout (Oncorhynchus mykiss). Infect Immun 64:3863-3869

- Misra CK, Das BK, Mukherjee SC, Phalguni P (2006) Effect of long term administration of dietary $\beta$-glucan on immunity, growth and survival of Labeo rohita fingerlings. Aquaculture 255:82-94

Nieto TP, Ellis AE (1991) Heterogeneity of extra-cellular proteases produced by different isolates of Aeromonas hydrophila and A. sobria pathogenic for fish. J Fish Dis 14:229-235

Oda K, Matsuda H, Murakami T, Katayama S, Ohgitani T, Yoshikawa M (2000) Adjuvant and haemolytic activities of 47 saponins derived from medicinal and food plants. Biol Chem 381:67-74

Park KH, Jeong HD (1996) Enhanced resistance against Edwardsiella tarda infection in tilapia (Oreochromis niloticus) by administration of protein-bound polysaccharide. Aquaculture 143:135-143

Punitha SMJ, Babu MM, Sivaram V, Shankar VS and others (2008) Immunostimulating influence of herbal biomedicines on non-specific immunity in grouper Epinephelus tauvina juvenile against Vibrio harveyi infection. Aquacult Int 16:511-523

Rahman MH, Kawai K (2000) Outer membrane proteins of Aeromonas hydrophila induce protective immunity in goldfish. Fish Shellfish Immunol 10:379-382

Rahman MH, Kawai K, Kusuda R (1997) Virulence of starved Aeromonas hydrophila to cyprinid fish. Fish Pathol 32: 163-168

Rairakhwada D, Pal AK, Bhathena ZP, Sahu NP, Jha A, Mukherjee SC (2007) Dietary microbial levan enhances cellular non-specific immunity and survival of common carp (Cyprinus carpio) juveniles. Fish Shellfish Immunol 22:477-486

Riguera R (1997) Isolating bioactive compounds from marine organisms. J Mar Biotechnol 15:187-193

Ruszala-Mallon V, Lin YI, Durr FE, Wang BS (1988) Low molecular weight immunopotentiators. Int J Immunopharmacol 10:497-510

Sahoo PK, Mohanty J, Mukherjee SC (1999) The three imunomodulators on haemotological parameters and immunity level in rohu (Labeo rohita) fingerlings. J Aquacult Trop 14:127-135

Sahu S, Das BK, Pradhan J, Mohapatra BC, Mishra BK, Sarangi N (2007) Effect of Magnifera indica kernel as a feed additive on immunity and resistance to Aeromonas hydrophila in Labeo rohita fingerlings. Fish Shellfish Immunol 23:109-118

Sivaram V, Babu MM, Citarasu T, Immanuel G, Murugadass S, Marian MP (2004) Growth and immune response of juvenile greasy groupers (Epinephelus tauvina) fed with herbal antibacterial active principle supplemented diets against Vibrio harveyi infections. Aquaculture $237: 9-20$

Editorial responsibility: John Austin, Oldendorf/Luhe, Germany
Siwicki AK, Anderson DP, Rumsey GL (1994) Dietary intake of immunostimulants by rainbow trout affects nonspecific immunity and protection against furunculosis. Vet Immunol Immunopathol 41:125-139

> Sommerset I, Krossoy B, Biering E, Frost P (2005) Vaccines for fish in aquaculture. Expert Rev Vaccines 4:89-101

Sritunyalucksana K, Sithisarn P, Withayachumnarnkul B, Flegel TW (1999) Activation of prophenoloxidase, agglutinin and antibacterial activity in haemolymph of the black tiger prawn, Penaeus monodon, by immunostimulants. Fish Shellfish Immunol 9:21-30

Tatefuji T, Izumi N, Ohta T, Arai S, Ikeda M, Kurimoto M (1996) Isolation and identification of compounds from Brazilian propolis which enhance macrophage spreading and mobility. Biol Pharm Bull 19:966-970

Thanga Viji V, Michael Babu M, Velmurugan S, Kumaran T, Anand SB, Gunasekaran P, Citarasu T (2011) Virulence factors and molecular cloning of outer membrane protein (OMP) gene from virulent Aeromonas hyrophila isolated from infected gold fish Carassius auratus. Bangladesh J Microbiol 28:70-75

Thanga Viji V, Michaelbabu M, Anand SB, Gunasekaran P, Citarasu $T$ (2012) Immunization with the Aeromonas OMP provides protection against Aeromonas hydrophila in goldfish (Carassius auratus). J Microb Biochem Technol 4:45-49

Tsai GJ, Tsai FC, Kong ZL (1997) Effects of temperature, medium composition, $\mathrm{pH}$, salt and dissolved oxygen on haemolysin and cytotoxin production by Aeromonas hydrophila isolated from oyster. Int J Food Microbiol 38: 111-116

- Van Kampen E, Zijlstra WG (1961) Standardization of hemoglobinometry 11 . The hemiglobincyanide method. Clin Chim Acta 6:538-544

Van Muiswinkel WB, Anderson DP, Lamers CHJ, Egberts E, Van Loon JJA, Ijssel JP (1985) Fish immunology and fish health. In: Manning MJ, Tatner MF (eds) Fish immunology. Academic Press, London, p 1-8

Vivas J, Razquin B, López-Fierro P, Villena AJ (2005) Modulation of the immune response to an Aeromonas hydrophila aroA live vaccine in rainbow trout: effect of culture media on the humoral immune response and complement consumption. Fish Shellfish Immunol 18: 223-233

- Vogel FR (2000) Improving vaccine performance with adjuvants. Clin Infect Dis 30(Suppl 3):S266-S270

Williams DL, Yaeger RG, Pretus HA, Browder IW, McNamee RB, Jones EL (1989) Immunization against Trypanosoma cruzi: adjuvant effect of glucan. Int J Immunopharmacol 11:403-410

Yin G, Jeney G, Racz T, Xu P, Jun X, Jeney Z (2006) Effect of two Chinese herbs (Astragalus radix and Scutellaria radix) on non-specific immune response of tilapia, Oreochromis niloticus. Aquaculture 253:39-47

Submitted: June 11, 2012; Accepted: January 29, 2013

Proofs received from author(s): March 31, 2013 